\title{
Influence of the Paracoccidioides brasiliensis 14-3-3 and gp43 proteins on the induction of apoptosis in A549 epithelial cells
}

\author{
Julhiany de Fátima da Silva', Juliana Vicentim', Haroldo Cesar de Oliveira', \\ Caroline Maria Marcos' ${ }^{1}$ Patricia Akemi Assato', Patrícia Ferrari Andreotti', \\ Juliana Leal Monteiro da Silva', Christiane Pienna Soares ${ }^{1}$, Gil Benard ${ }^{2,3}$, \\ Ana Marisa Fusco Almeida', Maria José Soares Mendes-Giannini ${ }^{1 /+}$ \\ ${ }^{1}$ Departamento de Análises Clínicas, Faculdade de Ciências Farmacêuticas de Araraquara, Universidade Estadual Paulista, \\ Araraquara, SP, Brasil ${ }^{2}$ Laboratório de Alergia e Imunologia Clínica e Experimental \\ ${ }^{3}$ Clínica de Doenças Infecciosas e Parasitárias, Faculdade de Medicina, Universidade de São Paulo, São Paulo, SP, Brasil
}

The fungal strain Paracoccidioides brasiliensis remains viable inside of epithelial cells and can induce apoptosis in this population. However, until now, the molecules that participate in this process remained unknown. Thus, this study evaluated the contribution of two P. brasiliensis molecules, the 14-3-3 and glycoprotein of $43 \mathrm{kDa}$ proteins, which had been previously described as extracellular matrix adhesins and apoptosis inductors in human pneumocytes. Accordingly, epithelial cells were treated with these molecules for different periods of time and the expression of the apoptosis regulating-proteins Bak, Bax, Bcl-2, p53 and caspases were evaluated by terminal deoxynucleotidyl transferase dUTP nick end labelling, flow cytometry and real-time polymerase chain reaction analysis. Our results demonstrated that treatment with these molecules induces apoptosis signalling in pulmonary epithelial cells, showing the same pattern of programmed cell-death as that observed during infection with P. brasiliensis. Thus, we could conclude that $\mathrm{P}$. brasiliensis uses these molecules as virulence factors that participate not only in the fungal adhesion process to host cells, but also in other important cellular mechanisms such as apoptosis.

Key words: Paracoccidioides brasiliensis - adhesins - apoptosis

Paracoccidioides brasiliensis is a pathogenic fungus and an etiological agent of paracoccidioidomycosis, a systemic mycosis with great importance in Brazil due the high concentration of endemic areas for this disease (Blotta et al. 1999, Coutinho et al. 2002). During its evolution, P. brasiliensis developed several features that allow its growth in adverse host conditions, leading to the establishment of a parasitic relationship and contributing to disease development (Mendes-Giannini et al. 1994, 2000). These features, known as virulence factors, promote infection and fungal pathogenesis by facilitating fungal adhesion, colonisation and evasion of the host immune response (Casadevall \& Pirofski 1999).

Both virulence factors and the defense mechanisms provided by the host require interactions among complex processes. Increased knowledge of these events allows a better understanding of the pathogenesis of systemic mycoses, such as paracoccidioidomycosis (Kurokawa et al. 1998, Mendes-Giannini et al. 2008).

The success of host tissue colonisation by P. brasiliensis is a complex event, generally involving codified adhesion molecules from the pathogen, known as

doi: 10.1590/0074-02760150057

Financial support: FAPESP, CNPq, CAPES

+ Corresponding author: giannini@ffffar.unesp.br

Received 11 February 2015

Accepted 20 April 2015 adhesins and a cell receptor (Mendes-Giannini et al. 2000) that makes the fungus capable of adhering to and invading epithelial cells (Mendes-Giannini et al. 1994). This phenomenon has been associated with the fungal virulence (Hanna et al. 2000). The identification of molecules that are involved in microorganism adhesion is of great importance because during dissemination through the host circulatory system, interactions of this nature constitute the first stages of innumerous infection (Ofek et al. 1996, Karkowska-Kuleta et al. 2009).

Modulating host cell apoptosis could eliminate key defense cells that are necessary to eradicate the pathogen, regulate pathogen replication or promote inflammation to aid in pathogen clearance or prevent it spread within tissues (Gao \& Kwaik 2000). The apoptotic program is inherent to all cells and seems to be related to pathogen internalisation in epithelial cells (Jacobson 1997, Jacobson et al. 1997, Vaux \& Korsmeyer 1999, Albert 2004). As a consequence, pathogens can reach the extracellular environment, eliminate phagocytic cells or stimulate the inflammatory response (Monack et al. 1996, Müller et al. 1996, Zychlinsky et al. 1996, Wronowska et al. 2005).

The regulators of apoptosis include a family of cysteine aspartic-proteases (caspases) that cleave specific target proteins and members of the Bcl-2 family. These factors control cell death through the initiation, signal transduction and execution of apoptosis. Caspases can be divided into the following two groups according to their structure and function: "initiator caspases" and "effector caspases" (Thornberry \& Lazebnik 1998). Caspase-9 and caspase-8 initiate cell death by cleaving inactive caspases, whereas 
other proteins, such as caspase-3, are terminal effectors that initiate cell death once they are activated by extrinsic (death ligand) and intrinsic (mitochondrial) pathways (Elmore 2007, Florentin \& Arama 2012).

Many Bcl-2 family proteins act as pro-apoptotic effectors (e.g., Bax and Bak) by forming ion channels at the outer mitochondrial membrane that regulate membrane permeability and the release of cytochrome c into the cytosol where it is capable of activating caspase-9, caspase-3 and anti-apoptotic effectors (including Bcl-2). This process promotes cell survival by binding to and suppressing the activities of the functionally competitive pro-apoptotic Bcl-2 family members, which express death signals (Perskvist et al. 2002, Lindsay et al. 2011, Czabotar et al. 2014).

Additionally, mammalian p53 is a tumour suppressor gene critically involved in cell cycle regulation, DNA repair and programmed cell death (Schuler et al. 2000). One of the most dramatic responses to p53 activation is the induction of apoptosis. Cells committed to die via p53-dependent apoptosis typically follow the mitochondrial pathway, although $\mathrm{p} 53$ can also modulate cell death through death receptors. The p53 protein has the ability to activate transcription of various pro-apoptotic genes, including those encoding members of the Bcl-2 family (Amaral et al. 2010).

It is well known that several pathogens can manipulate the activity and availability of caspases and Bcl-2 family proteins to manipulate cell death pathways. Mendes-Giannini et al. (2004) demonstrated that $P$. brasiliensis yeast cells can enter mammalian cells and manipulate the host cell environment to favour their own growth and survival. Furthermore, differences between attenuated and more virulent isolates (Del Vecchio et al. 2009) in terms of the extent of apoptosis induced by this fungal strain in infected epithelial cells was demonstrated in previous studies using various techniques such as terminal deoxynucleotidyl transferase dUTP nick end labelling (TUNEL), DNA fragmentation and Bak and Bcl-2 immunocytochemical. These studies showed that the modulation of apoptosis was dependent on the sample and the duration of P. brasiliensis infection (Del Vecchio et al. 2009).

Mendes-Giannini et al. (2004) and Del Vecchio et al. (2009) made important conclusions about the induction of apoptosis caused in cells infected with P. brasiliensis. DNA fragmentation in cells infected with $P$. brasiliensis was observed in both studies and, during the course of the infection, Bcl-2 and Bak expression levels remained unchanged until $24 \mathrm{~h}$ after infection, suggesting a competitive mechanism that allows for the infection to persist. However, overexpression of Bak was observed after $48 \mathrm{~h}$ of infection, leading to an induction of apoptosis, which can explain the efficient dissemination of $P$. brasiliensis. However, the $P$. brasiliensis molecules that influence in this phenomenon are unknown.

The $P$. brasiliensis antigenic structure is sufficiently complex, with approximately 60 soluble components described including glycoproteins and proteins with and without enzymatic activity (Arango et al. 1982). Studies of the correlations between some of these components and their pathogenic roles in are subjects of great importance.
The glycoprotein of $43 \mathrm{kDa}$ (gp43) elicits humoral, innate and protective cellular immune responses and binds to extracellular matrix-associated proteins partially responsible for yeast cell adhesion to the extracellular matrix. P. brasiliensis adhesion to Vero cells was inhibited by $85 \%$ following treatment with anti-gp 43 polyclonal serum (Hanna et al. 2000). Purified gp43 was able to bind to laminin-1 from mouse sarcoma at a $\mathrm{K}_{\mathrm{d}}$ of 3.7 $\mathrm{nM}$ (Vicentini et al. 1994), while laminin and fibronectin internal peptides competed for gp43 adhesion to the corresponding proteins (Mendes-Giannini et al. 2006). gp43 is the antigen most commonly used to study serological diagnosis and prognosis (Mendes-Giannini et al. 1989). Different fungal isolates can produce different gp43 isotypes with varying $\mathrm{pI}$ (isoelectric point) from 5.8-8.5 (Souza et al. 1997) and these proteins are differentially expressed among the isolates. On the other hand, various studies note that gp 43 peptides may have different functions than those previously described (Konno et al. 2012). The use of antibodies directed against the gp43 protein is also considered to be a good strategy for avoiding adhesion to different host cells.

The 14-3-3 protein of $P$. brasiliensis is an adhesin with the capacity to bind to laminin that is more abundantly expressed in P. brasiliensis isolates with greater adhesion capacities (Andreotti et al. 2005, da Silva et al. 2013) and frequently identified in P. brasiliensis extracellular vesicles (Vallejo et al. 2012). In a recent study, the recombinant 14-3-3 protein inhibited the adhesion of $P$. brasiliensis to epithelial cells. In addition, within in vitro and in vivo infection models, the 14-3-3 protein accumulated on fungal cell walls, suggesting that this protein could be involved in the modulation of different cellular processes, such as apoptosis, in addition to its role in adhesion (da Silva et al. 2013) and virulence (Oliveira et al. 2015).

Therefore, this study aimed to evaluate the involvement of $P$. brasiliensis 14-3-3 and gp43 proteins in the induction of apoptosis in epithelial cells, which contributes to the establishment and dissemination of paracoccidioidomycosis.

\section{MATERIALS AND METHODS}

Microorganisms - Strain 18 of P. brasiliensis was isolated from a clinical case of paracoccidioidomycosis and maintained in the Faculty of Pharmaceutical Sciences of Araraquara, São Paulo State University, Brazil, in Fava Netto medium (Fava Netto 1961) at $37^{\circ} \mathrm{C}$.

Epithelial cells - The cell line A549, a type II pneumocyte, was obtained from the American Type Culture Collection (USA). The cells were seeded for $24 \mathrm{~h}$ in HAM F-12 Nutrient (Cultilab, Brazil), supplemented with $10 \%$ heat-inactivated foetal calf serum (Cultilab) and maintained at $36.5^{\circ} \mathrm{C}$ and $5 \% \mathrm{CO}_{2}$, The formation of a cell monolayer was evaluated by optical microscopy.

Preparation of the 14-3-3 and gp43 proteins - The 14-3-3 protein was prepared by heterologous expression in Escherichia coli, as described by da Silva et al. (2013), and the gp43 protein was purified from crude exoantigen of $P$. brasiliensis, as previously described (Mendes- 
Giannini et al. 1989). Briefly, the exoantigen was fractionated by gel filtration chromatography on Sephacryl S-100 columns (Pharmacia-Biotech, USA) using AKTAFPLC (GE Healthcare, USA). Two-dimensional electrophoresis analysis was performed using IPGphor III (GE Healthcare), sodium dodecyl sulfate-polyacrylamide gel electrophoresis (SDS-PAGE) and Coomassie Blue Phast Gel R350 staining to show specific spots corresponding to molecular masses of $30 \mathrm{kDa}$ and $43 \mathrm{kDa}$, respectively.

Treatment of A549 cells with 14-3-3 protein and gp43 - A549 cells were cultured at $36.5^{\circ} \mathrm{C}$ in 24 -well plates and cell concentrations were adjusted to $1.0 \times 10^{6}$ cells per well. The cells were incubated for varying amounts of time ( $5 \mathrm{~h}, 24 \mathrm{~h}, 48 \mathrm{~h}$ and $72 \mathrm{~h}$ ) with $25 \mu \mathrm{g} / \mathrm{mL}$ of the appropriate protein (14-3-3 protein alone, gp43 alone or combined treatment with 14-3-3 protein with gp43) dissolved in HAM F-12 Nutrient medium. After incubation, the cells were washed three times with phosphate-buffered saline (PBS). In the negative control experiments, the A549 cells were not pre-incubated with any protein and the positive controls were performed using $1 \mathrm{mM}$ methotrexate (Zodiac ${ }^{\circledR}$, Brazil).

TUNEL assay - The TUNEL assay was performed as described by Zychlinsky et al. (1996). Epithelial cells were grown on glass coverslips and incubated for $5 \mathrm{~h}$ and $24 \mathrm{~h}$ with 14-3-3 and gp43 proteins, as previously described, washed and fixed with paraformaldehyde $4 \%$ in PBS. The coverslips were blocked with bovine serum albumin, permeabilised for $15 \mathrm{~min}$ with $0.2 \%$ Triton $\mathrm{X}-100$ and incubated with terminal D-transferase and fluorescent dUTP (Boehringer Mannheim, Germany). Apoptotic bodies were visualised and counted by fluorescence microscopy (Leica, Germany) using filter sets for fluorescein isothiocyanate (FITC) and flow cytometry (BD FACSCanto; BD Biosciences, USA). All experiments were repeated three times and performed in triplicate. The mean and standard deviation of at least three distinct experiments were determined. Statistical analysis was calculated by ANOVA (with Tukey posttest) using GraphPad Prism 5.0 software. Results were considered to be significant when $\mathrm{p}<0.05$.

Expression of pro and anti-apoptotic markers by flow cytometry analysis - Flow cytometry was performed using a FACSCanto (Becton Dickinson Immunocytometry System, USA) to study the expression of Bcl-2, Bak, p53, caspase-3, caspase- 8 and caspase-9. Epithelial cells were grown in six-well plates, adjusted to $1.0 \times 10^{6}$ cells per well and incubated with 14-3-3 protein and gp43 proteins, as previously described, for $5 \mathrm{~h}, 24 \mathrm{~h}, 48 \mathrm{~h}$ and 72 h. After incubation, the cells were separated by trypsinisation and then washed with a PBS and placed in $70 \%$ ethanol in PBS overnight at $4^{\circ} \mathrm{C}$. The cells were then washed three times in PBS and permeabilised with $1 \%$ saponin. The reaction was developed using anti-Bak, anti-Bcl-2, anti-p53, anti-caspase-3, anti-caspase- 8 and anti-caspase-9 antibodies diluted 1:200 in PBS. After three washes with PBS, the cells were incubated with FITC-labelled anti-mouse antibody for $30 \mathrm{~min}$, washed twice and resuspended in PBS. Negative controls using an irrelevant primary antibody were also prepared. Cells $(10,000 /$ sample) were analysed by flow cytometry. For quantitation and comparison, positive cell percentages and median fluorescence intensity values were calculated using FACSDiva software. Statistical analysis was completed using ANOVA (with Tukey post-test) in GraphPad Prism 5.0 software. Results were considered to be significant when $\mathrm{p}<0.05$.

Expression analysis of apoptotic/anti-apoptotic markers by real-time polymerase chain reaction (PCR) - The expression of apoptotic (Bax, Bak, caspase-3 and caspase-8) and anti-apoptotic (Bcl-2) markers was evaluated in A549 cells. Specific primers for each gene were synthesised (Table) and GADPH expression was used as the endogenous control.

For these experiments, epithelial cells were grown in $75 \mathrm{~mm}^{3}$ cell culture flasks, adjusted to $10^{8}$ cells $/ \mathrm{mL}$ and incubated with 14-3-3 protein and gp43 proteins (as previously described) for $5 \mathrm{~h}, 24 \mathrm{~h}, 48 \mathrm{~h}$ and $72 \mathrm{~h}$. After each incubation period, the cells were washed three times with PBS and were removed from the bottle using TRIzol reagent (Invitrogen Life Technologies, USA). RNA extraction was performed with Trizol according to the manufacturer's instructions. First-strand cDNA synthesis was performed using reverse transcriptase (RevertAidTM H Minus Reverse Transcriptase; Fermentas Life Sciences, Canada) and $1 \mu \mathrm{g}$ of total RNA.

The $25-\mu \mathrm{L}$ reaction mixture contained $1 \mu \mathrm{L}$ of cDNA, $12.5 \mu \mathrm{L}$ of Maxima ${ }^{\circledR}$ SYBR Green/ROX qPCR Master Mix (2X) (Thermo Scientific, USA) and $0.5 \mu \mathrm{M}$ of each primer. The reaction program was $50^{\circ} \mathrm{C}$ for 2 min, $95^{\circ} \mathrm{C}$ for $10 \mathrm{~min}$ and 40 cycles of $95^{\circ} \mathrm{C}$ for $15 \mathrm{~s}$ and the annealing and synthesis occurred at $60^{\circ} \mathrm{C}$ for $1 \mathrm{~min}$. Following the PCR, melt-curve analysis was performed, which confirmed that the signal corresponded to a single PCR product. Reactions were performed in an Applied Biosystems 7500 cycler. The data were analysed by the $2^{-\triangle \Delta C T}$ method. The cycle threshold values for the triplicate PCRs of each RNA sample were averaged and then the $2^{-\triangle \Delta C T}$ values were calculated. A sample that contained all reagents except untreated A549 cDNA was used as negative control. After 40 rounds of amplification, no PCR products were detected in this reaction. Three independent experiments were performed for each sample.

TABLE

Specific primers for apoptotic/anti-apoptotic A549 markers

\begin{tabular}{lc}
\hline Gene & Primer sequence (5'-3') \\
\hline Bak R & CTGCCAGGGAACAGAGAAGG \\
Bak F & GTTCTGTTGGGCCAGTTGT \\
Bax R & CCACAAAGATGGTCACGGTCTG \\
Bax F & GAACCATCATGGGCTGGACA \\
Bcl-2 R & CCTTGGCATGAGATGCAGGA \\
Bcl-2 F & GATTGATGGGATCGTTGCCTTA \\
GADPH R & TGGTGAAGACGCCAGTGGA \\
GADPH F & GCACCGTCAAGGCTGAGAAC
\end{tabular}


Statistics were performed using one-way ANOVA with Tukey's coefficient post-test using GraphPad Prism 5.0 software. The results of the statistical analysis were considered to be significant when $\mathrm{p}<0.05$.

\section{RESULTS}

Preparation of 14-3-3 and gp43 proteins - Specific spots corresponding to the respective molecular masses of gp43 and the 14-3-3 protein are shown in Fig. 1 to confirm the purity of these molecules used in the following experiments. These analyses were performed by two dimensional electrophoresis, SDS-PAGE and Coomassie Blue Phast Gel R350 staining.

TUNEL assay - To determine whether epithelial cells undergo apoptosis after treatment with $P$. brasiliensis molecules, DNA fragmentation was assessed by the TUNEL assay. Untreated A549 cells had approximately $1 \%$ apoptotic cells. After treatment with gp43 and the 14-3-3 protein for $5 \mathrm{~h}$, there was no significant increase in apoptotic cells when compared with the control. However, 24-h showed a significant increase of apoptotic cells of $4 \%$ when treated with 14-3-3 protein, $6 \%$ with gp43 and 10\% with both adhesins (Fig. 2). The results from 48-h and 72-h treatments were also evaluated, but there were no significant differences between these results and those obtained after 24-h treatment.

Evaluation of pro-apoptotic markers (Bak/Bax expression) - Fig. 3 shows the results of epithelial cell treatment with the 14-3-3 protein and gp43 for varying periods of time in relation to Bak expression by flow cytometry analysis. Within $5 \mathrm{~h}$ of treatment, a significant difference in Bak expression was observed between the treated and untreated cells. After $24 \mathrm{~h}$ of treatment with gp43 or both proteins (gp43 + 14-3-3), an increase of Bak expression was observed. After $48 \mathrm{~h}$, all treatments led to significant increases in Bak expression when compared with 24-h treatment and the control. The greatest increase in Bak expression was observed with gp43 treatment.

When the cells were treated with gp43, increase expression of Bax was observed by real-time PCR. Expression levels increased 271-fold by $24 \mathrm{~h}$ and 53 -fold by 48 h. Furthermore, Bax expression increased by 112 -fold

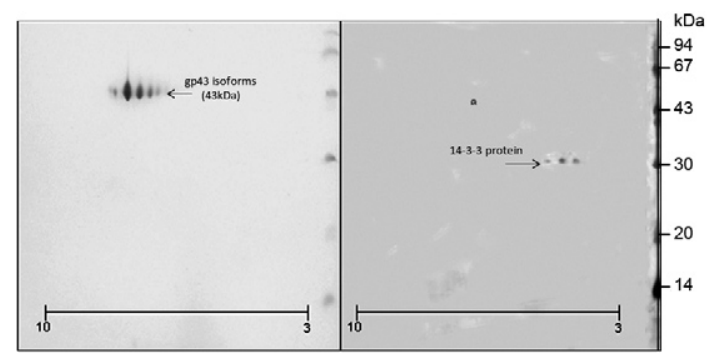

Fig. 1: two-dimensional electrophoresis showing the 14-3-3 $(30 \mathrm{kDa})$ and glycoprotein of $43 \mathrm{kDa}(\mathrm{gp} 43)$ after purification. Sodium dodecyl sulfate-polyacrylamide gel electrophoresis $12.5 \%$ stained with Coomassie Blue Phast Gel R350. Arrows indicates the 14-3-3 and gp43 proteins. after $24 \mathrm{~h}$ of treatment with gp43 and 3-fold after $48 \mathrm{~h}$ of treatment. The same pro apoptotic expression profile was observed by fluorescence-activated cell sorting, confirming the activation of these factors by gp 43 .

Evaluation of anti-apoptotic markers (Bcl-2 expression) - Bcl-2 expression was evaluated in cells after treatment with the 14-3-3 protein and gp43 by flow cytometry analysis. After $5 \mathrm{~h}$, decreased Bcl-2 expression was observed when cells were treated with 14-3-3 and 14-3-3 + gp43. Within $24 \mathrm{~h}$ of treatment, gp43 also led to a significant decrease in Bcl-2 expression. However, after $48 \mathrm{~h}$ of treatment with both molecules, a significant increase in Bcl-2 expression was observed followed by a significant reduction after $72 \mathrm{~h}$ of treatment (Fig. 4).

The same Bcl-2 expression profile was observed using real-time PCR. Following $24 \mathrm{~h}$ of treatment with 14-3-3, gp43 or both proteins, Bcl-2 expression was decreased by two-fold. After $48 \mathrm{~h}$ and $72 \mathrm{~h}$, no significant differences in BCL-2 expression were observed, indicating a possible loss of this pathway due to treatment.

Caspase expression - Fig. 5 shows the expression of caspases 8,9 and 3 determined by flow cytometry analysis after treatment with 14-3-3, gp43 or 14-3-3 + gp43. When treated with the 14-3-3 protein, caspase- 8 expression was significantly decreased after $5 \mathrm{~h}$, followed by a significant increase at $48 \mathrm{~h}$, thus reducing expression levels to those of the control after $72 \mathrm{~h}$ of treatment. gp 43 treatment increased caspase expression after $5 \mathrm{~h}$ and 72 $\mathrm{h}$ and maintained control levels of expression after $24 \mathrm{~h}$ and $48 \mathrm{~h}$. Combined 14-3-3 and gp 43 treatment increased caspase expression only after $72 \mathrm{~h}$.

For caspase-9, after $5 \mathrm{~h}$ of treatment, no differences in expression were observed; however, after $24 \mathrm{~h}$ and 48 $\mathrm{h}$, all treatments led to significantly increased caspase- 9 expression with the highest levels of expression observed for the treatment with 14-3-3 protein and the combina-
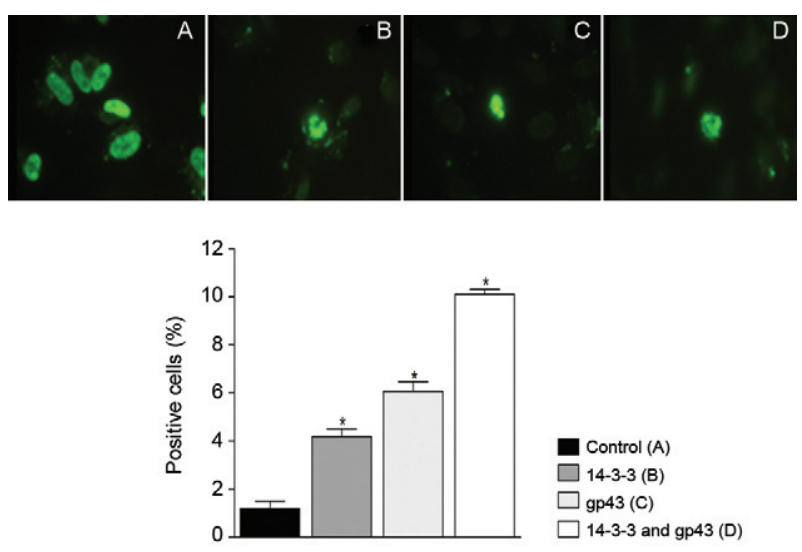

Fig. 2: DNA fragmentation by terminal deoxynucleotidyl transferase dUTP nick end labelling technique. Fluorescence microscope (right) and flow cytometry (left graph). Experiments carried out in triplicate for each treatment. Nontreated cells were used as control. Asterisk means $\mathrm{p}<0.05$. A: control; B: treatment with 14-3-3 protein; C: treatment with $43 \mathrm{kDa}$; D: treatment with 14-3-3 and $43 \mathrm{kDa}$; gp43: glycoprotein of $43 \mathrm{kDa}$. 


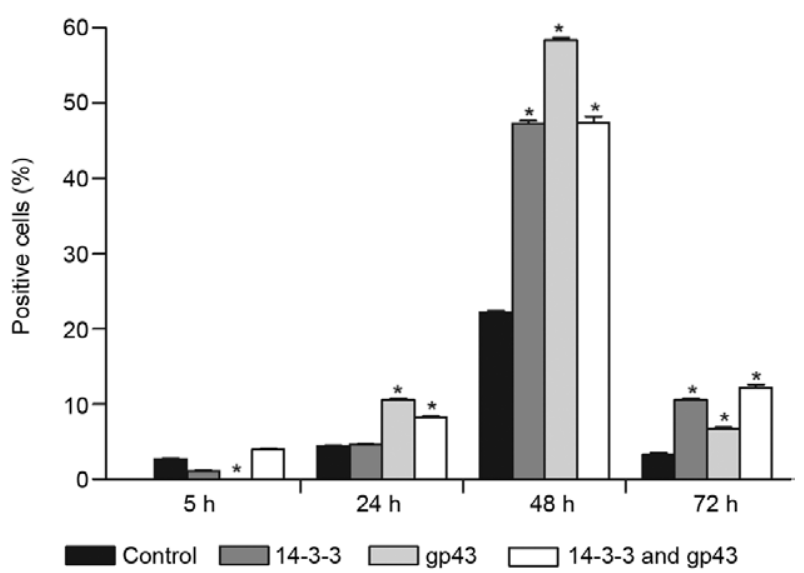

Fig. 3: bak expression in A549 cells with different treatments analysed by fluorescence-activated cell sorting. Asterisk means significant difference compared to the control $(\mathrm{p}<$ 0.05). gp43: glycoprotein of $43 \mathrm{kDa}$.

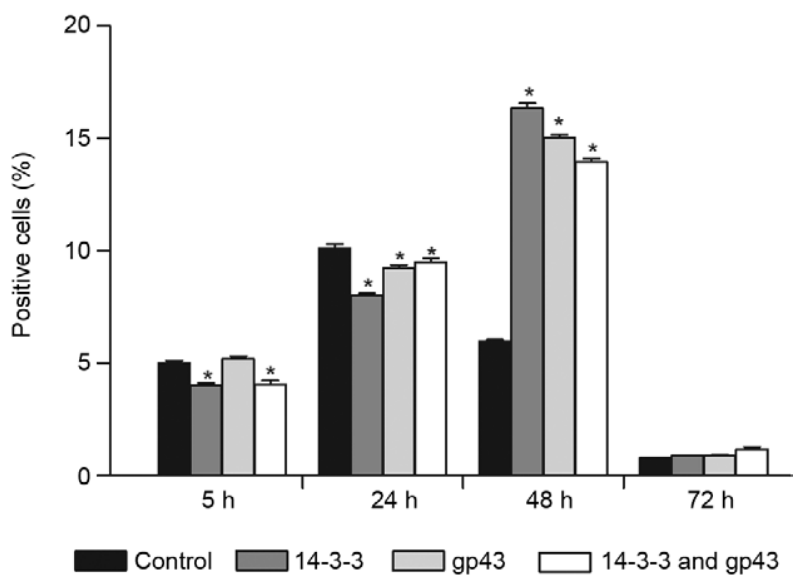

Fig. 4: Bcl-2 expression in A549 cells with different treatments analysed by fluorescence-activated cell sorting. Asterisk means significant difference compared to the control $(\mathrm{p}<$ 0.05). gp43: glycoprotein of $43 \mathrm{kDa}$.

tion of 14-3-3 and gp 43. After $72 \mathrm{~h}$, decreased caspase- 9 expression was observed following gp43 treatment, whereas the combined treatment resulted in increased caspase-9 expression compared with that of the control.

Treatment with the 14-3-3 protein induced a significant increase in the expression of caspase- 9 after $24 \mathrm{~h}$ and a significant decrease after $48 \mathrm{~h}$, equating the level of expression with the control in $72 \mathrm{~h}$. Treatment with gp43 increased caspase- 9 expression after $5 \mathrm{~h}$ and $24 \mathrm{~h}$ followed by a decrease after $48 \mathrm{~h}$, maintaining the same expression level as that of the control after $72 \mathrm{~h}$. The combined treatment increased expression after $24 \mathrm{~h}$ and $72 \mathrm{~h}$ with a decrease observed after $48 \mathrm{~h}$.

p53 expression - Fig. 6 shows the expression of the p53 protein after the treatment with $P$. brasiliensis molecules. Following $5 \mathrm{~h}$ of treatment, p53 expression was absent when the cells were treated with gp43 or left un-
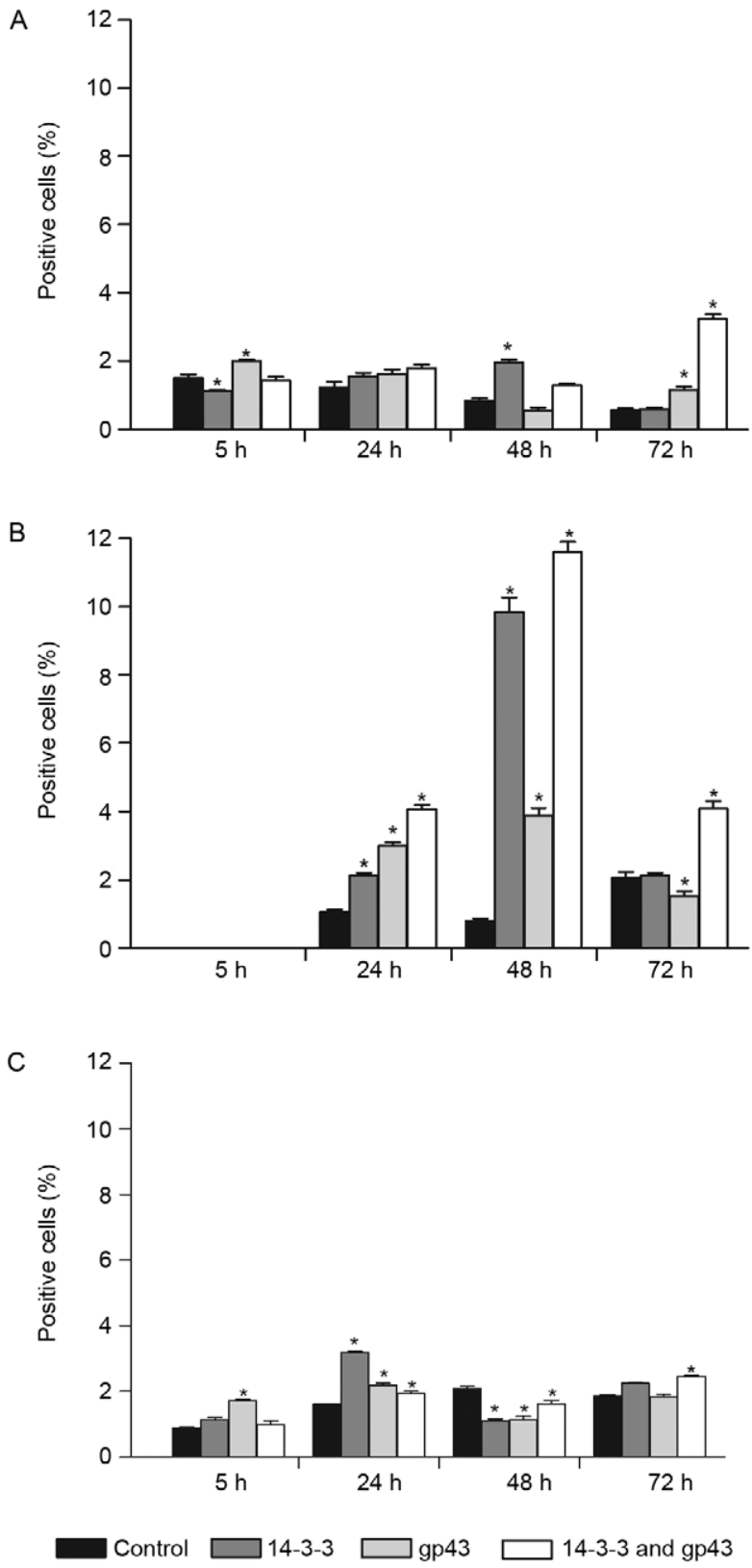

Fig. 5: caspase expression in A549 cells with different treatments. Caspase-8 (A), caspase-9 (B) and caspase-3 (C) analysed by fluorescence-activated cell sorting. Asterisk means significant difference compared to the control $(p<0.05)$. gp43: glycoprotein of $43 \mathrm{kDa}$.

treated. However, when the cells were treated with the 14-3-3 protein or both molecules, significantly increased p53 expression was observed. After $24 \mathrm{~h}$, the increase was more evident in cells treated with the 14-3-3 protein or both molecules and $\mathrm{p} 53$ expression remained absent when cells were treated with gp 43 alone. Following $48 \mathrm{~h}$ of treatment, all conditions led to increased p53 expression observed. After $72 \mathrm{~h}$, a reduction in p53 expression was observed relative to expression levels at shorter treatment intervals; however, p53 expression was still increased when compared with that of the untreated control. 


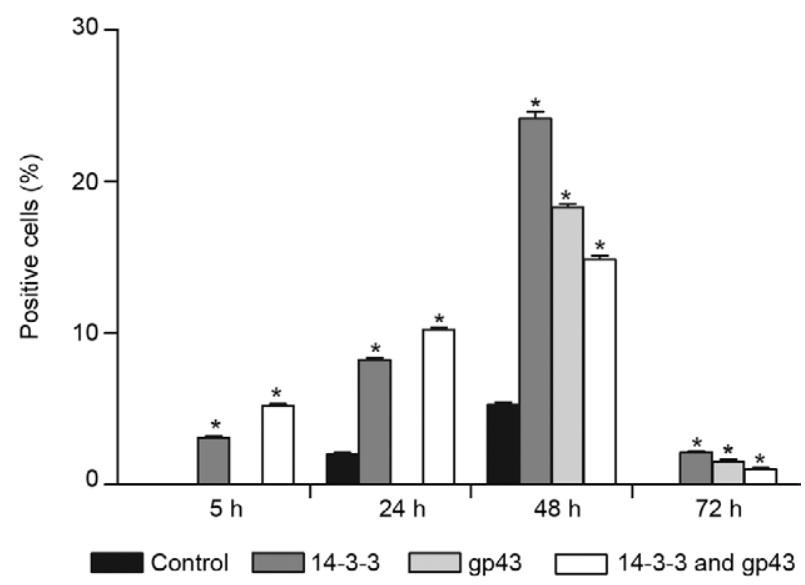

Fig. 6: the p53 expression in A549 cells with different treatments analysed by fluorescence-activated cell sorting. Asterisk means significant difference compared to the control $(\mathrm{p}<$ 0.05). gp43: glycoprotein of $43 \mathrm{kDa}$.

\section{DISCUSSION}

Induction of apoptosis in host cells has been implicated in microbial pathogenesis. In previous studies, the induction of apoptosis by $P$. brasiliensis was evaluated in epithelial cells and the number of apoptotic cells increased together with fungal exposure (Mendes-Giannini et al. 2004, Del Vecchio et al. 2009). This result suggests a requirement for internalisation of the fungus to trigger apoptosis in epithelial cells. However, the fungus molecules involved in apoptosis induction were unknown.

In the present study, the contribution of two P. brasiliensis molecules, gp43 and the 14-3-3 protein, to apoptosis induction in A549 cells were evaluated to elucidate the mechanisms used by the fungus to surpass host barriers and establish infection and subsequent dissemination. To this end, A549 cells were treated with both molecules for different periods of time and the extent of apoptosis was assessed by several techniques. Our results showed that the treatment with these molecules for $24 \mathrm{~h}$ led an increase in the number of apoptotic cells, indicating that these molecules are capable of inducing apoptosis.

The expression levels of the apoptosis regulating proteins Bak, Bcl-2 and caspases 3, 8 and 9 were also evaluated. Treatment with the 14-3-3 protein and/or gp43 did not increase Bak or Bcl-2 expression in relation to that of untreated cells at early time points $(5 \mathrm{~h})$. After $24 \mathrm{~h}$, gp43 treatment led to increased expression of Bak, but not Bcl-2, demonstrating the apoptosis induction of the tested molecules. After $48 \mathrm{~h}$ of treatment while Bak expression increased, expression of the anti-apoptotic protein $\mathrm{Bcl}-2$ also increased, although to a lesser extent than Bak. These results may suggest two possible mechanisms used by the fungus during infection. The first one indicates that the apoptosis induction through Bak expression leads to a cellular response by increasing Bcl-2 expression in order to avoid cell death. The second hypothesis could be that the fungus induces the expression of both Bak and Bcl-2 in order to damage the cell without killing it thus protecting itself from the host im- mune system. The behaviour found in these experiments was very similar to that reported by Mendes-Giannini et al. (2004) during P. brasiliensis infection.

The caspase pathway was also investigated and we determined that gp43, during early treatment intervals, promotes the activation of the extrinsic pathway through the activation of caspase- 8 , leading to the activation of caspase- 3 and the induction of apoptosis. On the other hand, 14-3-3 initially induces the activation of caspase-9 (24 h) while only after $48 \mathrm{~h}$ is caspase- 8 activated. After $48 \mathrm{~h}$, the induction of the intrinsic pathway is more prominent and the 14-3-3 protein appears to be predominantly responsible for this response.

In this study, when the cells were treated with gp 43 and 14-3-3 proteins, a significant increase in p53 expression was observed mainly after the treatment with the 14-3-3 protein when compared with untreated cells at all evaluated time points. The highest levels of p53 expression were observed after $48 \mathrm{~h}$ of treatment with both gp 43 and 14-3-3. p53 is involved in maintaining genome integrity maintenance through cell cycle progression inhibition or apoptosis induction (Fujita et al. 2002). Guinee et al. (1996) demonstrated that pneumocyte apoptosis is associated with p53 overexpression, proposing an apoptosis mechanism dependent of this molecule.

$P$. brasiliensis survival in the intracellular environment may act as a protective mechanism against immune responses and antimicrobial actions because nonprofessional phagocytes, such as pneumocytes, do not possess efficient microbicidal machinery similar to that of macrophages. However, it is speculated that apoptosis modulation is an advantage to the fungi because the cell death with internalised $P$. brasiliensis could provide a method for fungal dissemination. Apoptotic cells with internalised fungus would serve as a vehicle for the entrance in macrophages without the stimulation of the microbicidal activities.

The events that occur in infected epithelial cells with $P$. brasiliensis in vitro include adhesion, fungal translocation to the cytoplasm, multiplication and apoptosis induction. Correlation with pathogenicity mechanisms in vivo might elucidate the initial steps of the infection (Mendes-Giannini et al. 2005). Through apoptosis induction in macrophages, the microorganisms could evade the killing activity of the phagocyte antimicrobial machinery in tissues, thus preventing its proper death and stimulating the inflammatory response to invade the tissue as consequence of these injures (Bayles et al. 1998, Lewis 2000).

Many pathogens have surface proteins or secreted metabolites able to function as important inducers of apoptosis in the host cells. For example, it was demonstrated in Staphylococcus aureus that the invasion of endothelial cells causes induction of apoptosis and only occurs when the bacteria express a component called aflatoxin, which is the main participant in the induction of apoptosis in these cells. Previous studies have also demonstrated that this process is dependent upon virulence factors (Haslinger-Löffler et al. 2005). Another example of this process occurs in Yersinia sp., which express cell surface inv that is responsible for the adhesion and internalisation of this bacterium to intestinal epithelial cells and induce apoptosis (Superti et al. 2005). 


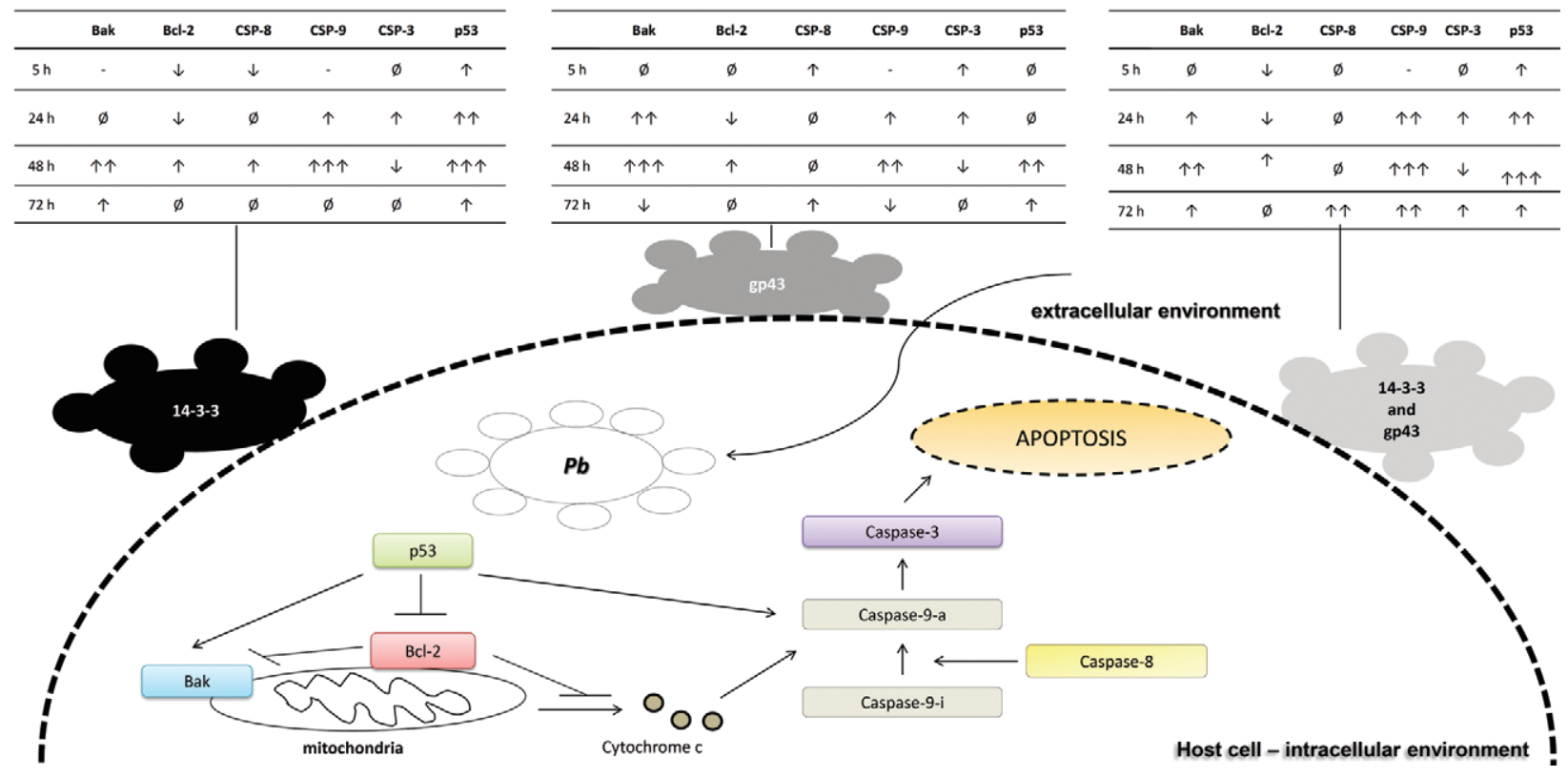

Fig. 7: schematic representation of the results obtained for the expression of components involved in apoptosis during the interaction of Paracoccidioides brasiliensis $(\mathrm{Pb})$ proteins [14-3-3 and glycoprotein of $43 \mathrm{kDa}$ (gp43)]. CSP: caspase; Ø: no difference in the expression compared to control; $\uparrow: 10-20 \%$ increase of expression compared to control; $\uparrow \uparrow: 20-30 \%$ increase of expression compared to control; $\uparrow \uparrow \uparrow: 30 \%$ or higher expression compared to control; $\downarrow: 10-20 \%$ decrease of expression compared to control; -: no expression.

In pathogenic fungi such as the obligate intracellular pathogen Histoplasma capsulatum, apoptosis is a critical element in the immune response and increased levels of interleukin (IL)-4 and IL-10 are observed when apoptosis is inhibited. Therefore, the increased release of these cytokines is directly proportional to the severity of infection (Allen \& Deepe 2005). Furthermore, upon $H$. capsulatum infection, caspases-3 and 1 are activated and both contribute to cell death; however, only the former is involved in apoptosis (Deepe \& Buesing 2012).

Panagio et al. (2002) studied a strain of Candida albicans that induced the appearance of phosphatidylserine in macrophage membranes, suggesting the induction of apoptosis as a virulence factor. Recently, it was demonstrated that in $C$. albicans, both the complement receptor 3) and dectin-1 play a crucial role in coordinating $\beta$-glucan-induced IL-1 $\beta$ processing as well as a cell death responses. In addition, this study also described an essential role for caspase- 1 and caspase- 8 in promoting $\beta$-glucan-induced cell death (Ganesan et al. 2014). These in vitro observations suggest that $C$. albicans induces apoptosis as a mechanism to evade host defenses.

Our results suggest that the $P$. brasiliensis 14-3-3 and gp43 proteins can induce apoptosis by modulating the caspase and p53 pathways. gp43 appears to be an important inducer of the extrinsic pathway and may be a very important molecule in the initial step of the infection, whereas 14-3-3 acts mainly in the intrinsic and p53 pathways and may be of great importance in the maintenance of the fungi in the host cells and consequently the fungal dissemination. All results are summarised in a comparative form in Fig. 7.
The mechanisms of invasion of host cells, persistence within them and the subsequent induction of apoptosis, may explain the efficient behaviour of $P$. brasiliensis in promoting tissue infection and/or blood dissemination (da Silva et al. 2007). We conclude with these findings that the $P$. brasiliensis 14-3-3 and gp43 molecules that act as adhesins and virulence factors also participate in many other important mechanisms that contribute to its pathogenesis, including apoptosis.

\section{ACKNOWLEDGEMENTS}

To Rosângela Aparecida Moraes da Silva, for technical assistance.

\section{REFERENCES}

Albert ML 2004. Death-defying immunity: do apoptotic cells influence antigen processing and presentation? Nat Rev Immunol 4: 223-231.

Allen HL, Deepe GS 2005. Apoptosis modulates protective immunity to the pathogenic fungus Histoplasma capsulatum. J Clin Invest 115: 2875-2885.

Amaral JD, Xavier JM, Steer CJ, Rodrigues CM 2010. The role of p53 in apoptosis. Discov Med 9: 145-152.

Andreotti PF, da Silva JLM, Bailão AM, Soares CM, Benard G, Soares CP, Mendes-Giannini MJ 2005. Isolation and partial characterization of a $30 \mathrm{kDa}$ adhesin from Paracoccidioides brasiliensis. Microbes Infect 7: 875-881.

Arango M, Oropeza F, Anderson O, Contreras C, Bianco N, Yarzábal L 1982. Circulating immune complexes and in vitro cell reactivity in paracoccidioidomycosis. Mycopathologia 79: 153-158.

Bayles KW, Wesson CA, Liou LE, Fox LK, Bohach GA, Trumble WR 1998. Intracellular Staphylococcus aureus escapes the endosome and induces apoptosis in epithelial cells. Infect Immun 66: 336-342. 
Blotta MH, Mamoni RL, Oliveira SJ, Nouér SA, Papaiordanou PM, Goveia A, Camargo ZP 1999. Endemic regions of paracoccidioidomycosis in Brazil: a clinical and epidemiologic study of 584 cases in the Southeast Region. Am J Trop Med Hyg 61: 390-394.

Casadevall A, Pirofski LA 1999. Host-pathogen interactions: redefining the basic concepts of virulence and pathogenicity. Infect Immun 67: 3703-3713.

Coutinho ZF, Silva D, Lazera M, Petri V, Oliveira RM, Sabroza PC, Wanke B 2002. Paracoccidioidomycosis mortality in Brazil (1980-1995). Cad Saude Publica 18: 1441-1454.

Czabotar PE, Lessene G, Strasser A, Adams JM 2014. Control of apoptosis by the BCL-2 protein family: implications for physiology and therapy. Nat Rev Mol Cell Biol 15: 49-63.

da Silva JF, de Oliveira HC, Marcos CM, da Silva RA, da Costa TA, Calich VL, Almeida AM, Mendes-Giannini MJ 2013. Paracoccidoides brasiliensis $30 \mathrm{kDa}$ adhesin: identification as a 14-3-3 protein, cloning and subcellular localization in infection models. PLOS ONE 8: e62533.

da Silva JLM, Andreotti PF, Benard G, Soares CP, Miranda ET, Mendes-Giannini MJ 2007. Epithelial cells treated with genistein inhibit adhesion and endocytosis of Paracoccidioides brasiliensis. Antonie Van Leeuwenhoek 92: 129-135.

Deepe GS, Buesing WR 2012. Deciphering the pathways of death of Histoplasma capsulatum-infected macrophages: implications for the immunopathogenesis of early infection. J Immunol 188: 334-344.

Del Vecchio A, da Silva JF, da Silva JLM, Andreotti PF, Soares CP, Benard G, Giannini MJSM 2009. Induction of apoptosis in A549 pulmonary cells by two Paracoccidioides brasiliensis samples. Mem Inst Oswaldo Cruz 104: 749-754.

Elmore S 2007. Apoptosis: a review of programmed cell death. Toxicol Pathol 35: 495-516.

Fava Netto C 1961. Contribuição para o estudo imunológico da blastomicose de Lutz (blastomicosesulamericana). Rev Inst Adolfo Lutz 21: 99-194.

Florentin A, Arama E 2012. Caspase levels and execution efficiencies determine the apoptotic potential of the cell. J Cell Biol 196: 513-527.

Fujita T, Maruyama M, Araya J, Sassa K, Kawagishi Y, Hayashi R, Matsui S, Kashii T, Yamashita N, Sugiyama E, Kobayashi M 2002. Hydrogen peroxide induces upregulation of Fas in human airway epithelial cells via the activation of PARP-p53 pathway. Am J Respir Cell Mol Biol 27: 542-552.

Ganesan S, Rathinam VA, Bossaller L, Army K, Kaiser WJ, Mocarski ES, Dillon CP, Green DR, Mayadas TN, Levitz SM, Hise AG, Silverman N, Fitzgerald KA 2014. Caspase-8 modulates dectin-1 and complement receptor 3 -driven IL-1 $\beta$ production in response to $\beta$-glucans and the fungal pathogen, Candida albicans. J Immunol 193: 2519-2530.

Gao LY, Kwaik YA 2000. The modulation of host cell apoptosis by intracellular bacterial pathogens. Trends Microbiol 8: 306-313.

Guinee D, Fleming M, Hayashi T, Woodward M, Zhang J, Walls J, Koss M, Ferrans V, Travis W 1996. Association of p53 and WAF1 expression with apoptosis in diffuse alveolar damage. $\mathrm{Am}$ J Pathol 149: 531-538.

Hanna SA, da Silva JLM, Giannini MJ 2000. Adherence and intracellular parasitism of Paracoccidioides brasiliensis in Vero cells. Microbes Infect 2: 877-884.

Haslinger-Löffler B, Kahl BC, Grundmeier M, Strangfeld K, Wagner B, Fischer U, Cheung AL, Peters G, Schulze-Osthoff K, Sinha B
2005. Multiple virulence factors are required for Staphylococcus aureus - induced apoptosis in endothelial cells. Cell Microbiol 7: 1087-1097.

Jacobson MD 1997. Apoptosis: Bcl-2-related proteins get connected. Curr Biol 7: R277-R281.

Jacobson MD, Weil M, Raff MC 1997. Programmed cell death in animal development. Cell 88: 347-354.

Karkowska-Kuleta J, Rapala-Kozik M, Kozik A 2009. Fungi pathogenic to humans: molecular bases of virulence of Candida albicans, Cryptococcus neoformans and Aspergillus fumigatus. Acta Biochim Pol 56: 211-224.

Konno FT, Maricato J, Konno AY, Guereschi MG, Vivanco BC, Feitosa LS, Mariano M, Lopes JD 2012. Paracoccidioides brasiliensis gp43-derived peptides are potent modulators of local and systemic inflammatory response. Microbes Infect 14: 517-527.

Kurokawa CS, Sugizaki MF, Peraçoli MT 1998. Virulence factors in fungi of systemic mycoses. Rev Inst Med Trop Sao Paulo 40: 125-135.

Lewis K 2000. Programmed death in bacteria. Microbiol Mol Biol Rev 64: 503-514.

Lindsay J, Esposti MD, Gilmore AP 2011. Bcl-2 proteins and mitochondria - specificity in membrane targeting for death. Biochim Biophys Acta 1813: 532-539.

Mendes-Giannini MJ, Andreotti PF, Vincenzi LR, da Silva JL, Lenzi HL, Benard G, Zancopé-Oliveira R, Guedes HLM, Soares CP 2006. Binding of extracellular matrix proteins to Paracoccidioides brasiliensis. Microbes Infect 8: 1550-1559.

Mendes-Giannini MJ, Bueno JP, Shikanai-Yasuda MA, Ferreira AW, Masuda A 1989. Detection of the 43,000-molecular-weight glycoprotein in sera of patients with paracoccidioidomycosis. $J$ Clin Microbiol 27: 2842-2845.

Mendes-Giannini MJ, da Silva JLM, da Silva JF, Donofrio FC, Miranda ET, Andreotti PF, Soares CP 2008. Interactions of Paracoccidioides brasiliensis with host cells: recent advances. Mycopathologia 165: 237-248.

Mendes-Giannini MJ, Hanna SA, da Silva JL, Andreotti PF, Vincenzi LR, Benard G, Lenzi HL, Soares CP 2004. Invasion of epithelial mammalian cells by Paracoccidioides brasiliensis leads to cytoskeletal re-arrangement and apoptosis of the host cell. Microbes Infect 6: 882-891.

Mendes-Giannini MJ, Ricci LC, Uemura MA, Toscano E, Arns CW 1994. Infection and apparent invasion of Vero cells by Paracoccidioides brasiliensis. J Med Vet Mycol 32: 189-197.

Mendes-Giannini MJ, Soares CP, da Silva JL, Andreotti PF 2005. Interaction of pathogenic fungi with host cells: molecular and cellular approaches. FEMS Immunol Med Microbiol 45: 383-394.

Mendes-Giannini MJ, Taylor ML, Bouchara JB, Burger E, Calich VL, Escalante ED, Hanna AS, Lenzi HL, Machado MP, Miyaji M, da Silva JLM, Mota EM, Restrepo A, Restrepo S, Tronchin G, Vincenzi LR, Xidieh CF, Zenteno E 2000. Pathogenesis. II. Fungal responses to host responses: interaction of host cells with fungi. Med Mycol 38 (Suppl. 1): 113-123.

Monack DM, Raupach B, Hromockyj AE, Falkow S 1996. Salmonella typhimurium invasion induces apoptosis in infected macrophages. Proc Natl Acad Sci USA 93: 9833-9838.

Müller A, Hacker J, Brand BC 1996. Evidence for apoptosis of human macrophage-like HL-60 cells by Legionella pneumophila infection. Infect Immun 64: 4900-4906.

Ofek I, Kahane I, Sharon N 1996. Toward anti-adhesion therapy for microbial diseases. Trends Microbiol 4: 297-299. 
Oliveira HC, Silva JF, Scorzoni L, Marcos CM, Rossi SA, de Paula e Silva ACA, Assato PA, da Silva RAM, Fusco-Almeida AM, Mendes-Giannini MJS 2015. Importance of adhesins in virulence of Paracoccidioides spp. Front Microbiol 6: 303.

Panagio LA, Felipe I, Vidotto MC, Gaziri LC 2002. Early membrane exposure of phosphatidylserine followed by late necrosis in murine macrophages induced by Candida albicans from an HIVinfected individual. J Med Microbiol 51: 929-936.

Perskvist N, Long M, Stendahl O, Zheng L 2002. Mycobacterium tuberculosis promotes apoptosis in human neutrophils by activating caspase-3 and altering expression of Bax/Bcl-xL via an oxygen-dependent pathway. J Immunol 168: 6358-6365.

Schuler M, Bossy-Wetzel E, Goldstein JC, Fitzgerald P, Green DR 2000. p53 induces apoptosis by caspase activation through mitochondrial cytochrome c release. J Biol Chem 275: 7337-7342.

Souza MC, Gesztesi JL, Souza AR, Moraes JZ, Lopes JD, Camargo ZP 1997. Differences in reactivity of paracoccidioidomycosis sera with gp43 isoforms. J Med Vet Mycol 35: 13-18.

Superti F, Pietrantoni A, Di Biase AM, Longhi C, Valenti P, Tinari A 2005. Inv-mediated apoptosis of epithelial cells infected with enteropathogenic Yersinia: a protective effect of lactoferrin. Res Microbiol 156: 728-737.

Thornberry NA, Lazebnik Y 1998. Caspases: enemies within. Science 281: 1312-1316.

Vallejo MC, Nakayasu ES, Matsuo AL, Sobreira TJ, Longo LV, Ganiko L, Almeida IC, Puccia R 2012. Vesicle and vesicle-free extracellular proteome of Paracoccidioides brasiliensis: comparative analysis with other pathogenic fungi. J Proteome Res 11: 1676-1685.

Vaux DL, Korsmeyer SJ 1999. Cell death in development. Cell 96: 245-254.

Vicentini AP, Gesztesi JL, Franco MF, de Souza W, de Moraes JZ, Travassos LR, Lopes JD 1994. Binding of Paracoccidioides brasiliensis to laminin through surface glycoprotein gp43 leads to enhancement of fungal pathogenesis. Infect Immun 62: 1465-1469.

Wronowska W, Godlewska R, Jagusztyn-Krynicka EK 2005. Influence of human gastrointestinal tract bacterial pathogens on host cell apoptosis. Postepy Biochem 51: 270-279.

Zychlinsky A, Thirumalai K, Arondel J, Cantey JR, Aliprantis AO, Sansonetti PJ 1996. In vivo apoptosis in Shigella flexneri infections. Infect Immun 64: 5357-5365. 